\title{
BESTRIJDING VAN DE APPELBLOESEMSNUITKEVER
}

\section{DOOR}

\author{
IR. P. Hus
}

Eenige jaren geleden werd in Fngeland waargenomen, dat in een stuk jute (zakkengoed) waarmee appelboomen aan een steunpaal bevestigd waren, vele appelbloesemsnuitkevers een schuilplaats gezocht hadden. Dit was voor den Heer Massee van het proefstation East Malling in Kent aanleiding om na te gaan of vangbanden, gemaakt van reepen zakkengoed, dienst konden doen bij de bestrijding van appelbloesemsnuitkevers.

Het bleek hem. dat dit inderdaad zeer goed mogelijk was. Vooral in de maanden Juni, Juli en October werden er in de vangbanden van zakkengoed vele kevers gevangen.

De vangmethode met dergelijke vangbanden werd in den zomer van 1929 geprobeerd in de omgeving van Hien (Betuwe), waar een ernstige beschadiging door de appelbloesemsnuitkever geconstateerd was.

Het resultaat is buitengewoon goed geweest. De banden zijn vrijwel elke maand nagezien. Oorspronkelijk was het de bedoeling telkens alle kevers, welke gevangen werden, te tellen, doch spoedig bleek dit niet uitvoerbaar. Van enkele banden is echter de maandelijksche vangst gecontroleerd.

Naar schatting zijn in een boomgaard met zware goudreinetten vanaf Juni 1929 tot Februari 1930 per band ongeveer 2000 kevers gevangen.

De gevolgen van deze groote vangst zijn dit jaar, ondanks den minder goeden bloei der goudreinetten, duidelijk zichtbaar geweest. Het aantal vernietigde bloesems (dompers, doodskoppen) was in den proefboomgaard aanmerkelijk kleiner dan in de boomgaarden in de onmiddellijke omgeving.

Het is gebleken, dat het vangen met banden van zakkengoed een uitstekende methode is, die met betrekkelijk weinig kosten practisch uitvoerbaar is.

In streken, waar de appelbloesemsnuitkevers zeer schadelijk optreden, is het gewenscht, dat de vangmethode algemeen toegepast wordt.

Reepen zakkengoed ter breedte van 20 à $25 \mathrm{~cm}$ moeten, hoogstens tweemaal, om den stam gewonden en met één touwtje, in het midden of boven aan, bevestigd worden.

Het beste is de banden eenige keeren per jaar, liefst maandelijks, af te nemen en de gevangen kevers te dooden. Zoodra de banden schoongemaakt zijn, moeten ze weer omgelegd worden. 